15. Hickey RJ (1977) The Lycopodium obscurum complex in North America. American Fern Journal 67:45-48.

16. Holub, J (1975) Diphasiastrum, a new genus in Lycopodiaceae. Preslia 14: $97-100$.

17. Harms VL (2003) Checklist of the vascular plants of Saskatchewan and the provincially and nationally rare native plants in Saskatchewan, including important synonyms, authorities, common names and various status indicators. University Extension Press, Saskatoon, SK
18. Cody WJ (1988) Plants of Riding Mountain National Park, Manitoba. Research Branch, Agriculture Canada, Publication 1818/E, Supply and services Canada, Ottawa, ON.

19. Tryon RM Jr (1954) The ferns and fern allies of Minnesota. University of Minnesota Press, Minneapolis, MN.

\title{
ECOSYSTEMS
}

\section{THE UKRAINIAN STEPPE: STATUS, THREATS AND PROMISES OF SUSTAINABILITY}

VLADIMIR V. KRICSFALUSY School of Environment and Sustainability, University of Saskatchewan, 330 Kirk Hall, 117 Science Place, Saskatoon SK S7N5C8, Canada vladimir.k@usask.ca

\section{INTRODUCTION}

Grasslands and savannas are found in most terrestrial ecoregions of the world and they cover over $40 \%$ of the land surface. ${ }^{1}$ Following the Pleistocene ice ages, grasslands expanded in range in the hotter and drier climates. Eventually, they became the dominant land feature worldwide. Nowadays, grasslands occupy more of the earth's surface than the other major cover types, i.e. forests or agricultural lands. Along with this huge sweep of area, grasslands are an immensely important environment for humans, plants and animals.
Grassland communities are characterized by rich biodiversity. The vegetation is dominated by grasses and other graminoids such as sedges. Grasses and many sedges are particularly suited for the specific ecological conditions because they have intercalary meristems that allow for continued growth under a grazing regime and help ensure survival in dry summers and cold continental winters. Most grassland plants also have a welldeveloped fibrous root system with a large surface area, a characteristic which is important under the condition of low soil moisture. 
Grasslands have been heavily used throughout millennia of human history. Globally, more people inhabit grasslands than any other biome. ${ }^{1}$ They provide many goods and services that are vital to humans: biodiversity, food, forage, livestock, biofuels, carbon storage, provision of drinking water, tourism and recreation, as well as playing other important supportive ecosystem functions. ${ }^{2}$ Grasslands are important repositories of biodiversity: they form one-quarter of 142 terrestrial ecoregions identified as priorities for conservation by WWF Global 200 and support nearly half of all endemic birds and one fifth of plant species. ${ }^{3}$ Grasslands have been the seedbeds for the ancestors of virtually every major cereal crop and the pre-domestication home of our most important livestock.

A long history of human use and abuse of grasslands has substantially shrunk their area around the world. Nowadays, the Temperate grasslands, savannas and shrublands biome has the least protection globally with mere $2 \%$ in strict protected areas. ${ }^{4}$ The greatest loss of grasslands is in North America. ${ }^{5,6}$ Current estimates indicate that, on average, less than $20 \%$ of original grassland habitats in the Central Plains remain, and only $3.5 \%$ has been protected overall within Canada., ${ }^{7,8}$ Locally, the loss of different grassland types can be even greater, e.g. in Saskatchewan, less than 1\% remains of the once vast fescue prairie. ${ }^{9}$ In Europe, grasslands are mostly of anthropogenic origin. ${ }^{10}$ The exceptions are the areas in alpine regions, along rivers and remnant fragments of steppe vegetation. ${ }^{11}$ Vast steppe grasslands that originally extended from south-east to central Europe have been destroyed to a greater degree than any other type of vegetation. The last big "taming of the steppe" occurred about 200 years ago in
Ukraine and nowadays about $82 \%$ of its steppe area is destroyed.

Most of the American prairies and European steppes were plowed by settlers, due to the extremely fertile soil. This has led to tremendous changes, and most recently, the loss of much of this biome occurred primarily due to agriculture, fragmentation, invasive exotic species, and the lack of a natural dynamic regime. The movement of herds of grazing animals and wildfire activity traditionally held back tree growth and invasive species, but with those factors largely gone, remaining grasslands are slowly reverting to woodland and forest. The main threats currently facing grasslands in Canada are changes in land use and abandonment of traditional activities, afforestation and intensification of grassland management. ${ }^{12,13}$

This short outlook illustrates the importance, multiple functions and threats to temperate grasslands in different parts of the world. The question one could ask is: why people on the Canadian prairies should be interested in the Ukrainian steppes? First, the steppes and the prairies have many biological similarities at the generic and even species level. Second, there are many examples of native plant species from one area that have become invasive weeds in the other. Third, plants from the steppe have become important forage and crop species in the prairie. Fourth, settlers from the Ukrainian steppe regions brought their agricultural expertise, seeds, and culture to the Canadian prairie provinces enriching the agricultural and cultural fabric. Therefore, the purpose of this paper is to describe the current state of the steppes of Ukraine, identify the main threats to them, and highlight the potential for collaboration of Canadian and Ukrainian scientists and practitioners in conserving temperate grasslands. 


\section{THE STEPPE ENVIRONMENT Ecology of the Steppe}

Grassland vegetation occurs mainly in lowland areas in the middle latitudes in areas with continental climate, where the summers are warm and dry and the winters are cold. Shortage of rainfall limits the growth of woody plants and prevents the development of a closed forest cover. Natural grasslands of the temperate zone of Eurasia are called the steppes. Russian and Ukrainian were the languages from which the term "steppe" was borrowed (etymology of the word is associated with the space, ground, and plain), first appearing in international botanical terminology in the $18^{\text {th }}$ century.

The Eurasian steppe stretches from an enclave in Hungary, where it called puszta (meaning "bare, empty"), through a chain of small remnants in Romania and Moldova to a vast area of south Ukrainian (Fig. 1) and south Russian plains, north Caucasus, south Ural, and north Kazakhstan to south Siberia, Mongolia and north-east China. ${ }^{14}$ Often the Eurasian steppe is divided into three main parts - the Pontic steppe, the Kazakh steppe, and the Mongol steppe. Similar vegetation types can also be found on other continents. In North America, common name for grasslands is the prairies (from French, meaning "a treeless grassy plain"). They form a triangular area from Alberta, Saskatchewan, and Manitoba in Canada through the Great Plains to southern Texas in the USA and down to Mexico. ${ }^{12}$

The Ukrainian steppe (Mariupol station) lies within the temperate continental climate zone and in comparison with the central part of the Eurasian steppe (Semipalatinsk station, Russia) or central part of the Canadian prairie (Saskatoon station), is milder and more moist (Fig. 2). Also, annual precipitation is more evenly distributed through the steppes in Eurasia than the prairies in North America. Overall, distribution and structure of steppe vegetation in Ukraine depends on climate and soil factors, and the main limiting factor of the vegetation is a lack of moisture..$^{15}$ The mean annual temperature and total precipitation change from south to north (from $9-10^{\circ} \mathrm{C}$ to $7-9^{\circ} \mathrm{C}$ and from $350 \mathrm{~mm}$ to $450 \mathrm{~mm}$, respectively).

The Eurasian steppe landscapes are characterized by far horizons and prevalent flat to undulating relief, mostly at low altitudes. A typical soil matrix is loess, which covers varied geological bedrock. The steppe ecosystem gave rise to the world's most fertile soils, chernozems (Russian and Ukrainian for "black soils") named after their characteristic darkcoloured humus horizon. The soils within steppe zone in Ukraine change from light and dark chestnut soils occurring in combination with solonetzic soils, through southern chornozems, to typical humic chernozems. Chernozem soil types also occur in the prairies of North America.

\section{Biodiversity of the Steppe}

The steppes of Ukraine are situated in the west part of the Eurasian temperate grassland biome and occupy about 300,000 square kilometers.

The characteristics of the pristine steppes of Ukraine were described in the beginning of the $19^{\text {th }}$ century by Pachoski $(1917)^{16}$, Kleopov (1933) ${ }^{17}$ and some other authors. Later, steppes became the subject of intense investigations by many Ukrainian and Russian scientists. Bilyk (1973) ${ }^{18}$ has summarized data on the steppe vegetation of Ukraine and gave a critical review of previous studies. There are zonal (geographical, ecological) patterns corresponding to the climate and soil patterns of the steppe community's distribution in Ukraine. ${ }^{15}$ Overall, vegetation changes towards the south from forest-steppe zone (which 


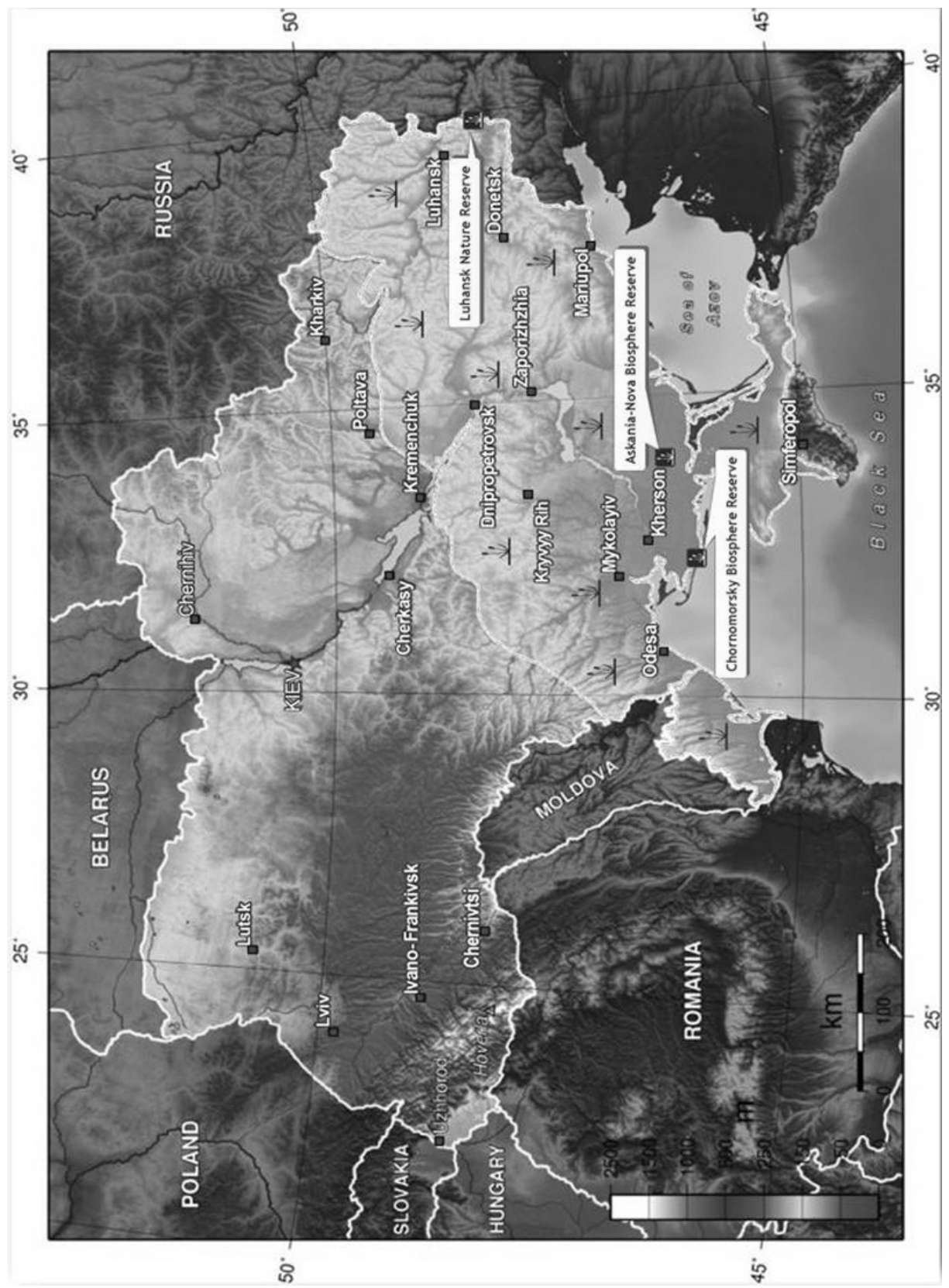

Figure 1. Map of the Ukrainian steppe with locations of the visited reserves [see back inside cover for colour version]. 


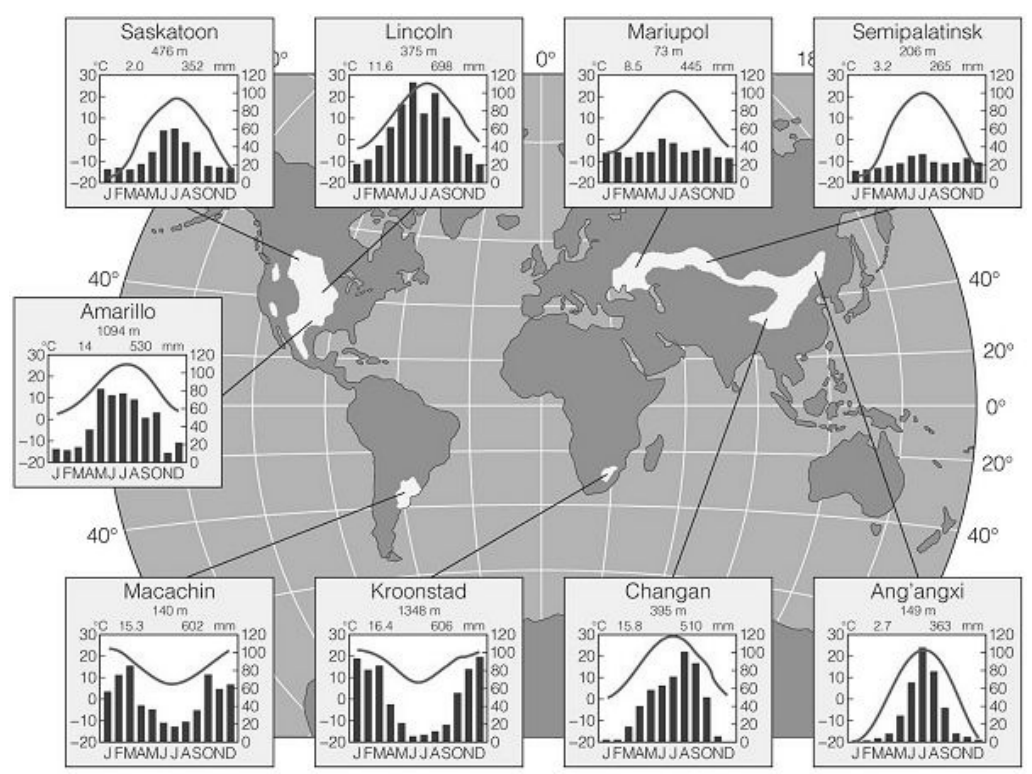

Figure 2. Climate diagrams for temperate grasslands. The diagrams include: name of station, elevation ( $m$ above sea level), mean annual temperature $\left({ }^{\circ} \mathrm{C}\right)$, mean annual precipitation $(\mathrm{mm})$, and months; left axis - mean monthly temperature $\left({ }^{\circ} \mathrm{C}\right)$, right axis - mean monthly precipitation $(\mathrm{mm}){ }^{39}$

exist as climatically determined belt between forests and steppes) to steppe zone. Meadow steppes in the northern part of steppe zone gradually change to true steppes in its central and southern parts. Stone steppes are scattered in the south-eastern part of steppe range in the Donetsk Upland while halophytic desert steppes are located along the Azov Sea and the Black Sea. Distribution of both stone and halophytic steppes is caused by soil factors. There are very diverse steppes on the Crimean peninsula as well. Their distribution is driven by an elevation gradient, which is manifested by changes in temperature, precipitation, and soil types.

Meadow steppes can be found as isolated islands completely surrounded by forests in forest-steppe zone or they form dominated vegetation type in the northern part of steppe zone. These grasslands on deep and very fertile chernozems are different from the much drier grasslands in central and particularly southern parts of steppe zone. They have a specific structure and peculiar species. In fact meadow steppes are often called 'hayfield steppes' which illustrates high quality fodder they provide and their general aspect.

Formerly, the majority of the northern Black Sea region was occupied by true steppes or herb-rich grass steppes (forb-rich fescue/feather-grass steppes). Nowadays, grass steppes (forb-poor fescue/feather-grass steppes) prevail. Their vegetation cover consists mainly of turf grasses from such genera as Stipa, Festuca, Poa, Koeleria and Agropyron as well as sedges (Carex). Compared to meadow steppes located to the north and true steppes, grass steppes have fewer forbs and increased participation of ephemeral plant species. This results from a drier climate and different soil types.

Blue Jay 
Stone steppes occur on poorly developed soils, slopes where erosion rates are particularly high, and often on rock outcrops (granites, limestones, and chalk). Compared to other steppe communities, stone steppes are less productive. However, the share of endemic plants is much higher than in the zonal steppe ecosystem because stone steppes served as refuges for many species during unfavourable climatic epochs. Perhaps vegetation of stone steppes and rock outcrops is not just a special variant of zonal steppe but an ancient floristic complex. Endemics and relics include many species, especially from such taxa as Astragalus, Oxytropis, Hedysarum, Stipa, and Dianthus.

Halophitic steppes, with a domination of sagebrush (Artemisia) species and grasses (Stipa, Elytrigia, and Puccinellia) occur on the saline soils mainly along the seacoasts and have limited distribution. However, this results from soil factors and is not caused by the climate. Usually they occur in combination with halophytic vegetation (solonetz, solonchak).

The flora of the Black Sea steppe region differs from other European floras in their great originality and richness. Studies of the flora have been conducted by many outstanding researchers (Besser, Ledebour, Pallas, and Shmalgausen just to name a few) and they date as far back as $18^{\text {th }}$ century. ${ }^{19}$ The Black Sea steppe represents the western border of the natural range of many plant species growing in the vast steppe zone of Eurasia. There is a significant number of species which were first described from the Black Sea steppe, including many relic and endemic (about 10\%) vascular plants. Among 826 vascular plants included in the national list of rare and endangered species - Red Data Book of Ukraine,${ }^{20} 276$ species $(33.4 \%$ of the total) occur in the different variants of steppes (including rock outcrops). Many rare and endemic species as well as species on the edge of its range that occur in the region (Fig 3,4) are included in the international list of rare and endangered species - European Red List ${ }^{21}$ and IUCN Red List of Threatened Plants. ${ }^{22}$

There are 31 steppe vegetation community types, each of which includes its own plant communities, listed in the Green Data Book of Ukraine. ${ }^{23}$ The Green Data Book of Ukraine is a very progressive document because its main focus is not on plant species protection but rather on biodiversity conservation within the entire plant community or habitat. This vision might be achievable only through the establishment of steppe habitat protection. However, the required baseline threatened habitat inventory has not yet been done in Ukraine. This lack of data prevents effective protection of all the most important steppe remnants and optimization of a network of nature protected areas.

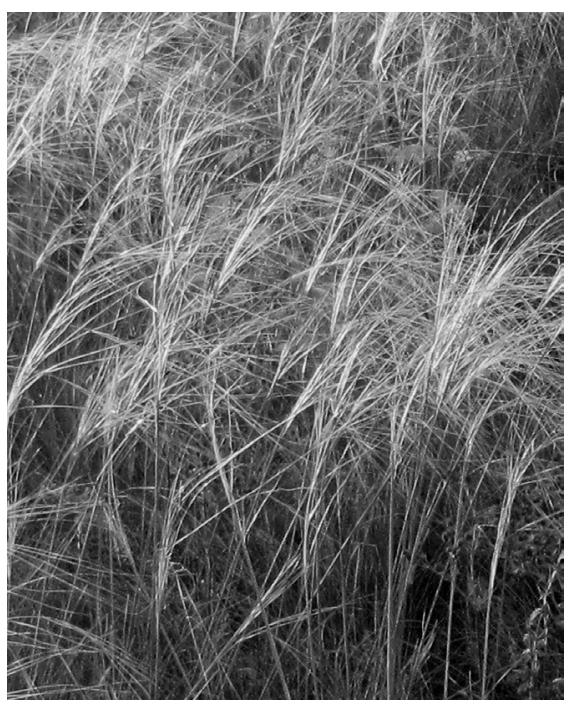

Figure 3. Iconic plant species Ukrainian feather-grass (Stipa ucrainica). 


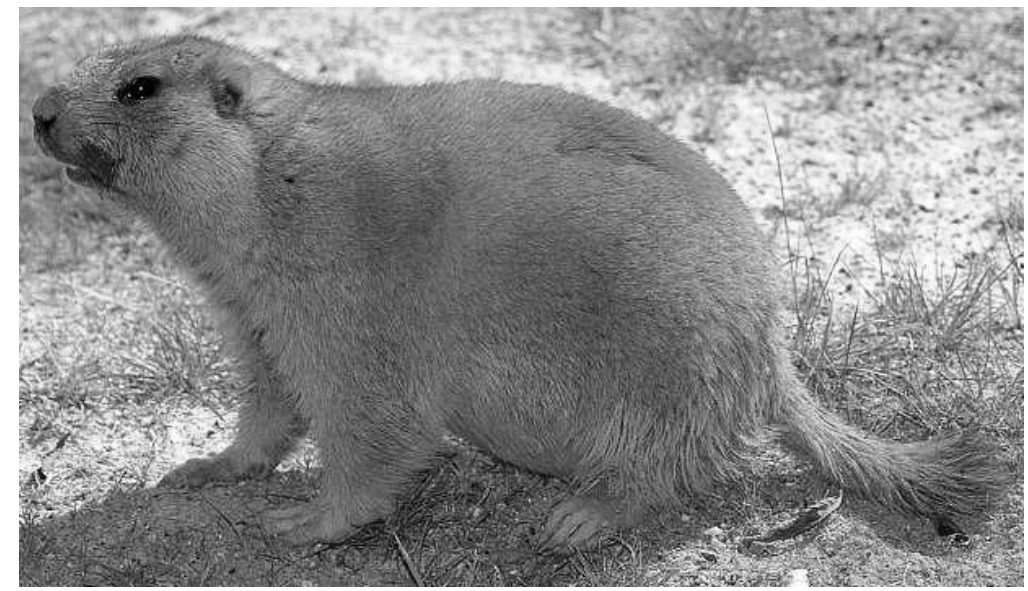

Figure 4. Iconic animal species steppe marmot (Marmota bobak)

\section{HUMAN COLONIZATION OF THE STEPPE}

The steppes of Ukraine represent a rich cultural legacy spanning almost eight millennia. According to Lillie, ${ }^{24}$ the emergence, development and decline of the Trypilian culture in Ukraine represents a significant stage in the history of the steppe zone during the prehistoric period (around 5500-2300 BC). The genesis and expansion of this culture coincides with the Holocene climate optimum when warm and humid climate, fertile soils, and lush grasslands intermingled with patches of broadleaved forests were at an ideal stage of evolution for the expansion of agriculture. It is believed that increasing climate aridity after around 3500-3200 BC caused instability in the Trypilia farming economy, finally leading to stockbreeding and specialized pastoralism. These changes created a base for a diverse range of new cultural groups formed at the transition to the Bronze Age. The culture grouping reflected growing socioeconomic, political, and ritual differences among tribes and shaped a new nomadic type of culture in the steppe zone of Ukraine.

Later, in Classical antiquity, the Black Sea steppe corresponds to Scythia and
Sarmatia. These steppes were used by numerous nomadic tribes, many of which went on to conquer lands in the settled regions of western and central Europe and in western and southern Asia. Over two thousand stone statues (called "babas") from the Scythian (the $7^{\text {th }}$ century $\mathrm{BC}$ ) to the Polovets (Kipchak or Kuman) and other cultures of 9-13 $3^{\text {th }}$ centuries (Khazars, Slavs, Tatars, Mongols, etc.) are scattered across the steppe zone. There are also many kurgans, also called barrows or burial mounds, which form a characteristic and unique element of the steppe landscape with specific flora and many threatened plant species. ${ }^{25}$

The Ukrainian steppe formed an important component of the modern nation's psyche. The steppes are closely related to issues of cultural wealth and history, and are reflected in folklore and songs. They are exclusively associated with the free life of the Zaporozhskyi Cossacks. The steppes were an important natural and geographic factor in the development of Ukraine's nomadic stockraising and agricultural ancestors. The wide open space of the steppes was the place where traditional trades and crafts were established and where cultural traditions and habits evolved. 
The final waves of colonization of the steppes, exploiting its rich chernozems, iron ore and coal deposits, happened in the $16^{\text {th }}$ to $18^{\text {th }}$ centuries when they were brought under the control of a sedentary peoples of different ethnic and religious backgrounds: Ukrainians, Russians, Jews, and Germans, as well as Mennonites, Poles, Tatars, Greeks, Bulgarians, and others. ${ }^{26}$ Due to the agricultural revolution on the steppes, Ukraine, in a short period of time, became the "breadbasket" of Europe.

Because of political discrimination against ethnic and religious minorities by the Russian Empire institutions during the 19th century, tens of thousands of people left the Ukrainian steppes to open up the Canadian prairie frontier. These immigrants introduced wheat from Ukraine to the New World, and it was used to develop successful varieties of Canadian wheat, such as Marquis. ${ }^{27}$ All this heavily contributed to the settlement of the prairies, and sparked an economic boom in Canada. By the middle of $20^{\text {th }}$ century Saskatchewan became the new "breadbasket" - the largest wheat producer in the world. Indeed, steppes and prairies have been a blessing for both Ukraine and Canada. It is our generation's task to rescue them from degradation and save this treasure for the future.

\section{CHALLENGES AND OPPORTUNITIES IN THE STEPPE \\ The Steppe in Transformation}

The steppe occupied more than $40 \%$ of Ukraine in the past. Many years ago herds of European wild horse or tarpan (Equus ferus Boddaert) and steppe antelope or saiga (Saiga tatarica L.) roamed these steppes, golden eagles (Aquila chrysaetos L.) hovered in the sky, and great bustards (Otis tarda L.) performed their awkward flights. Unfortunately, that time has passed. Total destruction of steppe ecosystem started $150-200$ years ago when large-scale colonization began to exploit its natural resources. The high population density and availability of rich chernozems induced a full-scale tilling of the steppe. The last large areas of steppe were plowed during the Soviet Union kolkhoz (collective farm) campaign to expand food production in favour of annual crops. Nowadays, the steppe is almost completely plowed: therefore virgin vegetation occurs almost exclusively on terraces of river valleys, steppe ravines (called "balka" in Ukrainian), steep slopes, and eroded lands. Large areas of steppe also survived as military training grounds. However, even these steppe remnants might disappear because of privatization and under the impact of artificial forest plantation.

Such a significant steppe loss put them at the center of public interest and drew the attention of nature conservationists and scientists. Several natural reserves were established to protect representative variants of steppe vegetation. However, today, only a handful of areas remain where truly natural steppe vegetation is found. Steppe communities occupy less than $3 \%$ of the country and steppe protected areas cover only about $1 \%$.

Despite the odds, there is a new ecological opportunity for the steppes after the collapse of Soviet-era kolkhoz (large collective farms) farming. The collapse of socialism resulted in rapid and drastic changes in political, societal and economic structures. This affected land use and the provision of ecosystem services in a profound way. During the last two decades, Ukraine gradually abolished large collective farms and divided up the land among the small landowners. Most productive land was quickly leased by big agribusiness companies. However, large areas of less productive farmland that once were pastures (some of them never were plowed) or overused croplands are now fallow. 


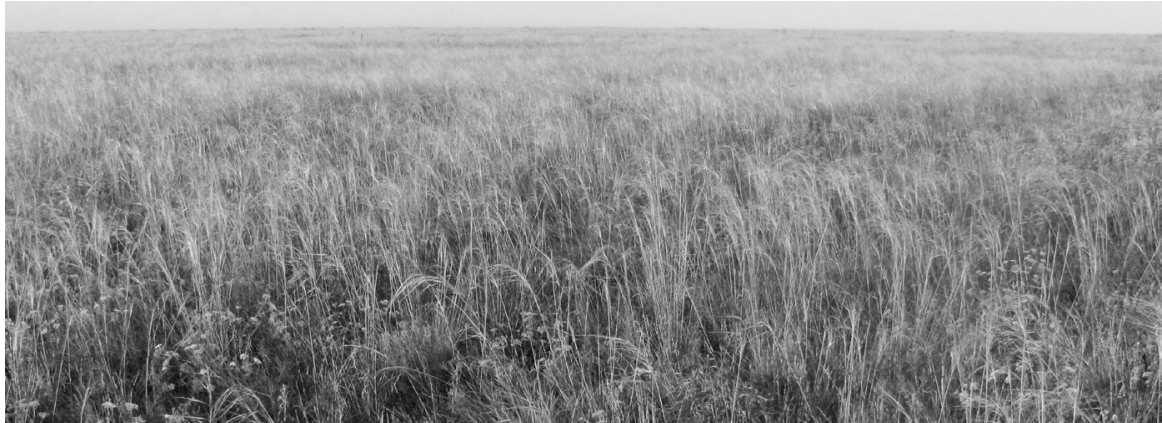

Figure 5. Halophytic steppe in Chornomorsky Biosphere Reserve, site Tendrivska Bay (Kherson oblast, Ukraine).

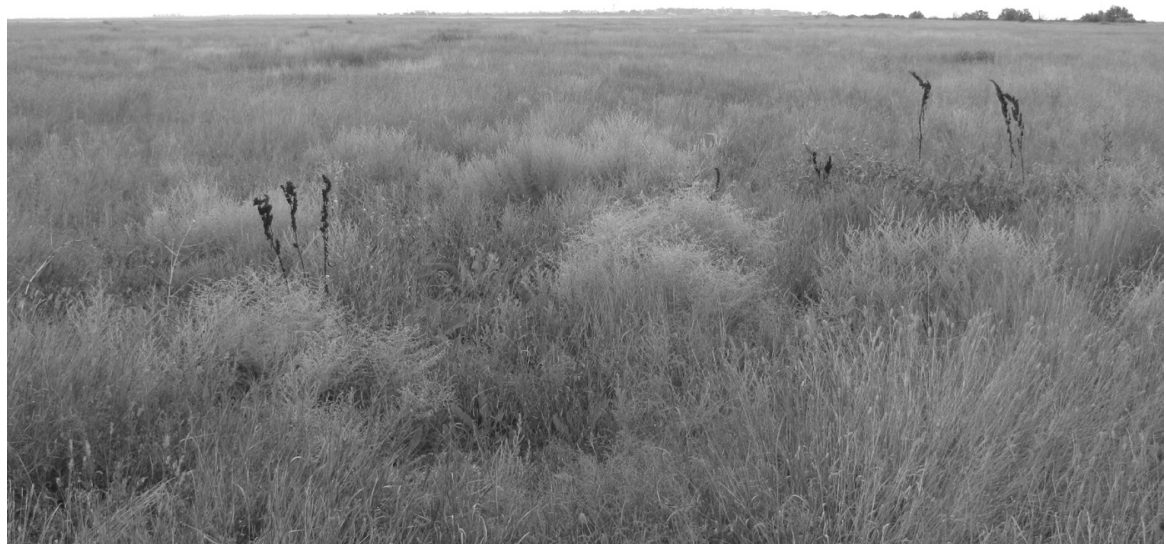

Figure 6. True steppe in Askania-Nova Biosphere Reserve (Kherson oblast, Ukraine).

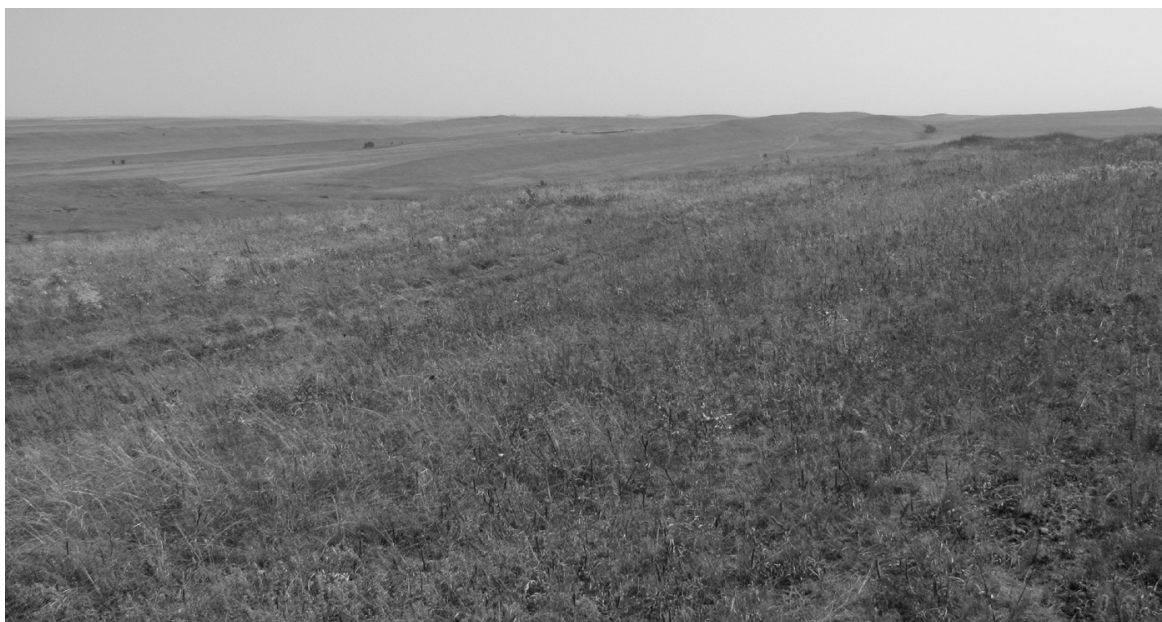

Figure 7. Stone steppe in Luhansk Nature Reserve, site Provalsky Steppe (Luhansk oblast, Ukraine). 
According to Charles $^{28}$ there is a growing interest among farmers in Ukraine, particularly in Luhansk province, to bring back the steppes through reseeding of this abandoned land with native plant species, the introduction of a grazing regime and the raising of high-quality beef cattle. This will also assist in restoring a traditional Ukrainian cattle breed, known as Red Steppe, which survived in Askania-Nova Biosphere Reserve. In my opinion, establishing regional learning centers to encourage farmers and environmental organizations to work together to reverse land degradation might be quite promising. These public and private lands can be managed using livestock as a tool to promote their recovery at low cost. They can sustain abundant wildlife and healthy rural communities once again.

Some of the steppe biosphere reserves and national parks with high tourism potential are prepared to seek mutually beneficial forms of cooperation with the business community. This may involve projects which, on the one hand, make a profit, but on the other, help to restore nature, rather than harm it. State budget funds typically are only sufficient to pay salary to its staff and maintain very limited activities. In such a situation, reserve management is only possible with the involvement of private investment. However, Ukrainian business has not yet realized the benefits of such investments. Therefore, it is still very rare, although a desire of park administrations to cooperate with investors often determines how quickly and successfully a project will be implemented. It should be noted that many directors are concerned about such initiatives and believe that business should not participate in nature conservation projects. In their view, businessmen are primarily interested in leasing land from reserves in order to exploit it unsustainably, which is essentially prohibited by existing law. Transfer of land through different leasing schemes can discredit the nature protection idea and some of the steppe areas even might lose their original function.

\section{The Canadian-Ukrainian Collaboration}

To explore the link between biodiversity conservation and sustainability in the Canadian prairies and the Ukrainian steppes, we have initiated research collaborations and field visits in both countries. This initiative was made possible through a grant from International Development Research Centre (IDRC), Canada obtained in 2010-2011. The long-term goal of this program is to examine how human impact on temperate grasslands and climate change can be mitigated through improved professional practice and collaboration in natural resources management.

The main participants in the conservation and sustainability in the Canadian prairies and the Ukrainian steppes project are scientists (Dr. V. Kricsfalusy) and graduate students (A. Henderson) from School of Environment and Sustainability at the University of Saskatchewan and respectively from M.G. Kholodny Institute of Botany, National Academy of Sciences of Ukraine (Dr. M.V. Shevera) and Luhansk Taras Shevchenko National University (O.V. Kucher).

Project participants have met with their academic partners as well as with representatives of conservation organizations in Canada (Grasslands National Park, Cypress Hill Interprovincial Park, and Redberry Lake Biosphere Reserve) and nature protection institutions in Ukraine (Chornomorsky Biosphere Reserve, Askania-Nova Biosphere Reserve, Luhansk Nature Reserve, and Svyati Hory National Park). Each meeting 
brought together conservationists, specialists, and scientists to discuss and identify the common threats and common solutions for conserving temperate grasslands.

During the field visits project participants sampled the variety of dry grassland types in both geographical and ecological terms. We found wonderful grassland communities, rich in plant species, including some endemics. We analyzed flora, vegetation and biodiversity of various grasslands in the selected study areas. We also used available literature and Internet resources to provide scientific background for the characterization of the visited areas.

The effectiveness of such learning exchanges, aimed at building the collaboration to conserve grasslands has recently been shown by Curtin and Western $^{29}$ with the example of African and American pastoralists, ranchers, scientists, and conservationists. The authors argue that such interchanges can speed up learning and adaptation by reaching beyond local circumstances and experience.

Apart from the gathering of valuable scientific data, project participants aimed to include a cultural exchange, given the fact that the steppes of Ukraine were the ancestral homeland for several ethnic and religious groups (Ukrainians, Germans, Mennonites, Hutterites, and Doukhobors) who settled on the Canadian prairies in the $19-20^{\text {th }}$ centuries. ${ }^{30}$ Also, we believe that this project will help to fill a gap in academic discourse regarding the steppes of Ukraine and break linguistic barriers that have limited access to this topic for most Western researchers.

\section{CONSERVATION OF THE STEPPE The Steppe Reserves}

The joint field visits of the international research group were conducted in the province of Saskatchewan, Canada and in Kherson, Luhansk, and Donetsk oblasts (regions) of Ukraine during July 26-August 5, 2010. Here we characterize only the visited locations in the southeastern Ukraine (Fig. 1).

\section{Chornomorsky Biosphere Reserve.}

The biosphere reserve ("Chornomorsky" is "the Black Sea" in Ukrainian) is situated on the northern coast of the Black Sea on the territory of Kherson oblast (small part of its area extends to Mykolaiv oblast). The reserve was established in 1927 and became the biosphere reserve in 1984 . Its area totals 89,129 ha, with 70,509 ha of core zone. The terrestrial part of the biosphere reserve includes only 14,148 ha. The relief is very flat, and the altitude is $0-8 \mathrm{~m}$ above sea level (a.s.I.). Sand arenas are a mosaic of 3-5 $\mathrm{m}$ tall hillocks alternated with numerous depressions along the sea coast. Sands are underlined with limestone.

The biosphere reserve represents shallow water sea bays, wetlands and temperate grasslands. Within the terrestrial habitats major interest represents forest-steppe on alluvial sands with oak (Quercus robur), birch (Betula borysthenica), and plum (Prunus stepposa). Unique seaside halophyte bunch-grass steppe occurs only in two sites - Potiyivska (1064 ha) and Yagorlytskyi Koot (840 ha). Here steppe vegetation stretches up to coastal saline meadows that are moist but rarely flooded. These habitats support fescue (Festuca valesiaca), alkali-grass (Puccinellia fominii), and couch-grass (Elytrigia pseudocaesia) communities. The flora of the biosphere reserve includes over 700 species of vascular plants (including 60 endemics), 24 of which are listed in the Red Data Book of Ukraine ${ }^{20}, 17$ in the European Red List ${ }^{21}$ and 7 in the IUCN Red List. ${ }^{22}$ 
The fauna of the biosphere reserve includes 452 species, among them 86 species of fish. Sixty-nine fauna species are listed in the Red Data Book of Ukraine,$^{20}$ and 12 in the IUCN Red List. ${ }^{22}$ The aviafauna of the area is particularly rich and totals 306 bird species (of which 110 are nesting here), including over 20 rare and endangered species listed in the Red Data Book of Ukraine. ${ }^{20}$ Among them are white-tailed eagle (Haliaeetus albicilla), demoiselle crane (Anthropoides virgo), great white pelican (Pelecanus onocrotalus), little bustard (Tetrax tetrax), etc. The biosphere reserve is also important place for many migratory birds. The reptiles are represented by rare Renard's meadow viper (Vipera ursinii renardii) and four-lined snake (Elaphe quatuorlineata).

Site 1: Chornomorsky Biosphere Reserve (core zone), $1 \mathrm{~km}$ west of the town of Zalizny Port (Fig. 5). The altitude is $0 \mathrm{~m}$ a.s.I., 4600 $07.82^{\prime \prime} \mathrm{N}$, $32^{0} 14^{\prime} 02.67^{\prime \prime} \mathrm{E}$. The site lies in close proximity to Tendrivska Bay of the Black Sea. The terrain is very flat, with small potholes sometimes filled with water that comes from the bay during heavy sea storms. Species richness value is high, and we registered 32 vascular plant species at $100 \mathrm{~m}^{2}$ plot. Vegetation of the site is represented by halophytic steppe community dominated by fescue (Festuca valesiaca) and feather-grass (Stipa capillata). Total vegetation cover is $60 \%$. The most common species of the upper canopy are feather-grass ( $S$. lessingiana, S. ucrainica), brome-grass (Bromus riparius), hedgenettle (Stachys recta), couch-grass (E. pseudocaesia), etc. In the lower canopy occur fescue ( $F$. pallens), crested wheat-grass (Agropyron pectinatum), June-grass (Koeleria cristata), santonica (Artemisia cina), knapweed (Centauria breviceps), Regel's onion (Allium regelianum), pasqueflower (Pulsatilla pratensis) and other forbs.
Askania-Nova Biosphere Reserve.

The biosphere reserve is situated south-east of the town Kakhovka in southern part of Kherson oblast. The natural reserve was established here in 1888 by Baron F. Falz-Fein of German ancestry who dedicated part of his estate to nature conservation, making this area the biggest preserved steppe in Europe. In 1993 it received the status of the biosphere reserve, with dendrological and zoological parks. Total area is 33,308 ha (core zone 11,054 ha), altitude 18-30 m a.s.l. Dominant types of soils within the area are chernozems and dark brown soils, gley soils rarely occur in terrain depressions.

The major habitats are zonal steppe and bushy steppe communities dominated mainly by different species of feathergrass (S. lessingiana, S. ucrainica, etc.), intermingled with fescue ( $F$. valesiaca) and June-grass (K. cristata) in some place. The flora of the biosphere reserve includes 515 species of vascular plants, 20 of which are listed in the Red Data Book of Ukraine ${ }^{20}$ and 6 are included into the IUCN Red List. ${ }^{22}$ There are also 53 endemic plant species, 7 of which are local endemics and occur only on the territory of the biosphere reserve.

The animal world of the biosphere reserve is typical for steppe landscapes. It is inhabited by 29 mammal species, 9 species of amphibians and reptiles, 8 fish species, and 272 species of birds. Overall, 73 species of vertebrates and invertebrates are listed in the Red Data Book of Ukraine. ${ }^{20}$ Among common animals are little ground squirrel or souslik (Spermophilus pygmaeus), steppe marmot or bobak (Marmota bobak), great jerboa (Allactaga major), steppe polecat (Mustela eversmanii), red fox (Vulpes vulpes), etc. Herds of wild hoofed animals from different continents are held here all year round under near- 
natural conditions: American bison (Bison bison), steppe antylope or saiga (Saiga tatarica), Przhevalski's horse (Equus ferus przewalskii), Turkmenian wild ass or kulan (Equus hemionus kulan), etc. In summer, common eland (Taurotragus oryx), wildebeest or gnu (Connochaetes gnou), blue antelope (Hippotragus leucophaeus) which are extinct in the wild, common zebra (Equus quagga) and other animals join them.

Site 2: Askania-Nova Biosphere Reserve (core zone), 1,5 km east of the town of Askania-Nova (Fig. 6). Altitude $28 \mathrm{~m}$ a.s.I., 46²7'21.74"N, 3354'2.37"E. Vegetation of the site is represented by true steppe community dominated primarily by different species of feathergrass ( $S$. ucrainica, with subdominance of $S$. lessingiana and $S$. capillata). This is a typical plain steppe ("plakorny" in Ukrainian) which occupies flat areas with uniform ecological conditions and well developed soil cover. This might explain lower species richness (23 per $100 \mathrm{~m}^{2}$ ) of this site compare to the halophytic steppe (Site 1) or stone steppe (Site 3 ). Total canopy cover is about $65 \%$. Upper canopy is formed by turf grasses (Stipa spp.) and some species of forbs: thistle (Carduus uncinatus), alfalfa (Medicago romanica), eryngo (Eryngium campestre), bedstraw (Galium ruthenicum), toadflax (Linaria macroura), and statice (Goniolimon tataricum). In the lower canopy were registered fescue ( $F$. valesiaca), June grass ( $K$. cristata), wormwood (Artemisia austriaca), milk-vetch (Astragalus henningii), and other forbs. A well-developed group of ephemeroid plants is present in this community during the spring season. It is formed by such plant species as yellow star-of-Bethlehem (Gagea bulbifera), tulip (Tulipa schrenkii), iris (Iris pumila), etc. There is a moss and lichen layer as well.
Luhansk Nature Reserve, Provalsky Steppe massif.

Provalsky Steppe is one of three separated massifs of Luhansk Nature Reserve to which it was included in 1975. Provalsky Steppe is situated south-east of the town Sverdlovsk near village Provallya in Luhansk oblast on the border with Rostov oblast of Russia. Total area of the nature reserve is 587,5 ha. It lies within Donetsk Upland, the most eastern part of the highest mountain range of the region. The relief is very hilly, altitude 150-230 $\mathrm{m}$ a.s.l. The terrain is divided by deep ravines and valleys. Sandstone, limestone and sandy shale are key components in the geological composition of the area. Prevailing soils are gravelly chernozems, loams and silt loams.

The nature reserve represents the unbroken stony steppe dominated by sheep's grass (Festuca ovina) and different species of feather-grass ( $S$. capillata, S. ucrainica, S. dasyphylla, etc.), which is rare for Ukraine. Specific petrophytous-steppe communities, where calciphilous species dominate, have been established in the nature reserve on the poorly developed and eroded stony soils on outcrops of limestone along Donetsk Upland and in some places on ravine slopes. Oak woodlands (Q. robur) with different species of maple (Acer tatarica, A. campestre), apple (Malus sylvestris) and pear (Pyrus communis) are scattered in ravines and flood plains of Provallya river. Flora of the nature reserve is very rich and includes 792 vascular plants, among them 135 endemic species. Twenty-nine vascular plants (among them 11 species of feather-grass) listed in the Red Data Book of Ukraine,${ }^{20}$ and 7 species are included into the IUCN Red List. ${ }^{22}$

The animal world of the nature reserve is characterized by presence of steppe, forest and semi-desert species. The list 
of fauna species includes 47 mammals, 174 birds, 9 reptiles, and 6 amphibians. Sixty-eight species are included into the Red Data Book of Ukraine ${ }^{20}$ and 22 are listed by the IUCN Red List. ${ }^{22}$ Among rare mammals occur Southern birch mouse (Sicista subtilis), great jerboa (A. major), steppe polecat (Mustela eversmanii), marbled polecat (Vormela peregusna) and others. Rare reptiles are represented by Renard's meadow viper (V. ursinii renardii), Caspian whipsnake (Dolichophis caspius), and four-lined snake (E. quatuorlineata).

Site 3: Luhansk Nature Reserve, Provalsky Steppe massif (Site Pivnichny, core zone). Seven $\mathrm{km}$ east of the village Provallya (Fig. 7). Altitude $173 \mathrm{~m}$ a.s.l., $48^{\circ} 8^{\prime} 45.89^{\prime \prime} \mathrm{N}, 39^{\circ} 53^{\prime} 25.77^{\prime \prime} \mathrm{E}$. The forbfescue-needle grass community occupies the middle and lower part of north facing slope on chornozems. Species richness value is very high, totalling 41 vascular plants in a $100 \mathrm{~m}^{2}$ plot. Total vegetation cover is about $65 \%$. It has three-layer structure, with heights $40-60 \mathrm{~cm}$. The studied vegetation community was mostly dominated by feather-grass (S. pennata) and forbs. Graminoids were represented by fescue (F. valesiaca, F. pallens), feather-grass ( $S$. capillata), Junegrass ( $K$. cristata), meadow-grass (Poa versicolor), and sedge (Carex humilis). The stand was very rich in perennial forbs, with species such as speedwell (Veronica incana), dianthus (Dianthus andrzejowskianus), wormwood (Artemisia marschalliana), dropwort (Filipendula vulgaris), medow-rue (Thalictrum minus), eryngo (Eryngium campestre), sandwort (Arenaria biebersteinii), cinquefoil (Potentilla arenaria), inula (Inula aspera), yarrow (Achillea millefolium), mullein (Verbascum vernum), clover (Trifolium alpestre), trina (Trina kitaibelii), forget-menot (Myosotis popovii) and many others. The ground layer is formed by different species of mosses and lichens.

\section{Long-Range Forecast}

Whether the remnants of the steppe, even if under protection, are capable of stable existence and recovery remains questionable. The ecological structure and function of the steppe ecosystem is damaged and its area is so small that the native vegetation can no longer successfully spread into nearby abandoned fields. Also, intensive human uses of the previously native steppes and now agricultural landscape modification brought invasive alien plants. Most of them are noxious weeds that may prevent natural recovery of steppe ecosystems on abandoned agricultural lands or slow this process for decades. We observed a growing trend of transcontinental exchange with invasive plants between Ukraine and Canada. ${ }^{31,32}$ There are several plant species native to Canada, e.g. Canadian horseweed [Conyza canadensis (L.) Cronquist] and Canada goldenrod (Solidago canadensis L.) currently threatening the steppe ecosystems of Ukraine and vice versa - some species from the latter region, for example, dog-strangling vine [Cynanchum rossicum (Kleopov) Barbarich], become severe invaders in Canada. Only recently have researchers started to analyze problem of shared invaders, possible relationships between invasive alien plant distribution, species traits and habitats in native ranges and by new invaded regions. ${ }^{33}$

The disappearance of permanent components of steppe biota which are extremely important for its existence - ungulates and burrowing animals - led to the destabilization of steppe ecosystem. ${ }^{34.35}$ Despite that, some forms of human activity which simulated natural impact were able to stabilize the steppe ecosystem. That is why establishment of nature reserves to protect steppe remnants only made things worse. Xerophyte turf grasses are forced out by 
mesophyte rhizomatous herbs. Provision of a mowing regime alone cannot halt this type of succession, even if it inhibits invasion by woody plants. ${ }^{36}$ Liberated from the impact of stabilizing factors of human activity, the steppe ecosystem is quickly being transformed into shrub-tree complexes. In many places trees and shrubs are spreading fast, as some of them are very aggressive, e.g. Russian peashrub [Caragana frutex (L.) K. Koch] and buckthorn (Rhamnus cathartica L.). In addition to this, foresters "contributed" to the problem of afforestation by converting remnants of steppes through planting trees.

Nowadays, because of afforestation and climate change, steppe ecosystem degradation is greatly accelerated. According to recent studies, ${ }^{15}$ special programs aimed to conserve the biodiversity of the Ukrainian steppe should be implemented and expanded. Unfortunately, all nature reserves visited during this trip are currently underfunded and hardly able to maintain their infrastructure, let alone support research projects. Fortunately, a traditional monitoring program with strong long-term components is still carried out.

Throughout all visited protected areas concerns were expressed over land encroachment, conflict with wildlife, weak governance, and growing population poverty. The consensus reached by scientists and conservationists was that reducing the downward spiral of environmental degradation and biodiversity loss can be achieved through raising public awareness, increasing local community participation, enhancing sharing of knowledge, and ensuring international partnerships. The replacement of confrontation with collaboration between antagonistic groups such as private land owners and conservationists is a high priority.
There is also a slow paradigm shift from traditional balanced nature protection to dynamic nature conservation among scientists and practitioners, which is a significant barrier for introducing modern management in steppe conservation. To conserve steppe reserves, policies of absolute non-intervention should be abandoned. Managerial practices on steppe lands (grazing, burning, etc.) should be implemented to slow down succession and conserve biodiversity of the ecosystems.

Without any doubt the Ukrainian steppe should be at least locally restored and better protected. It must be ensured that economic growth and resource development take place in an environmentally sensitive manner and that decisions taken reflect the interests of current and future generations. These decisions should enable integration of biodiversity concerns into agricultural policy and further strengthened measures for farmland and biodiversity. This would be also consistent with the Pan-European Biological and Landscape Diversity Strategy (1996) $)^{37}$ and the European Landscape Convention (2000). ${ }^{38}$ The European Commission does recognize multiple functions and values of grasslands and developed different tools to protect them.

\section{CONCLUSIONS}

The main threats currently facing the Ukrainian steppes are similar to the problems experienced by the Canadian prairies - including changes in land use, abandonment of traditional activities, loss of large-scale dynamic processes, and climate change. Additional threats to steppes in Ukraine are land privatization, afforestation, insufficient management practices in protected areas, and growing poverty of the rural population. Issues such as habitat loss and fragmentation, native species decline and exotic species 
invasion, and management use of grazing and fire are of common concern in both countries.

Given the complexity of threats to the Ukrainian steppe, more detailed studies would be a high priority in order to understand the causes underlying their biodiversity patterns. The steppe plant species and communities represent an outstanding and highly valuable part of world's natural heritage that needs more efficient conservation efforts, particularly as many of the stands are threatened by land use and other changes. Considering the growing global demand for bioenergy, carbon sequestration, food, and the importance of biodiversity conservation it is clear that the steppes of Ukraine should be one of focal regions of the world in this context.

Field visits and other activities have the potential to be substantially enhanced in the areas of research translation and learning exchanges between Canadian and Ukrainian partners. This might be achieved through joint research projects of mutual interest, collaboration between scientists, conservationists and local communities in both countries to improve the management of natural resources. These activities can help build not only ecological resilience of steppe ecosystems, but also increase overall human well-being in rural areas. If carefully managed and planned, sustainable development and biodiversity can go hand in hand and reinforce each other.

This project was conducted with financial support from the International Development Research Centre (IDRC), Canada. Additional support was provided by the School of Environment and Sustainability, University of Saskatchewan.
I would like to thank Prof. S.L. Mosyakin, M.G. Kholodny Institute of Botany, National Academy of Sciences of Ukraine and Dr. V.A. Kostiushyn, I.I. Schmalhausen Institute of Zoology, National Academy of Sciences of Ukraine, for fruitful discussions and their insights about the steppes of Ukraine. Project participants are very grateful to the staff and institutions that assisted with the field studies in Ukraine: Dr. Z.V. Seliunina and Dr. O.Yu. Umanets (Chornomorsky Biosphere Reserve), Dr. V.V. Shapoval (Askania-Nova Biosphere Reserve), and A.V. Bondarenko (Luhansk Nature Reserve).

I thank Dr. J. Schmutz (University of Saskatchewan) and G. Miller (Toronto and Region Conservation Authority) for their comments on the early draft of this paper as well as Meng Li and Sharla Daviduik for technical assistance in preparing this paper.

1. White R, Murray A and Rohweder M (2000) Plot analysis of global ecosystems: grassland management. World Resources Institute, Washington, DC.

2. Gibson D (2009) Grasses and grassland ecology. Oxford University Press, University of Oxford, UK.

3. Olson D and Dinerstein E (2002) The global 200: priority ecoregions for global conservation. Annals of the Missouri Botanical Garden 89:199-224.

4. Hoekstra JM, Boucher TM, Ricketts TH, Roberts C (2005) Confronting a biome crisis: global disparities of habitat loss and protection. Ecological Letters 8:23-29.

5. Samson F and Knopf F (1994) Prairie conservation in North America. BioScience 44:418-421. 
6. Riley JL, Green SE, and Brodribb KE (2007) A conservation blueprint for Canada's Prairies and Parkland. Nature Conservancy of Canada. Toronto, Ontario.

7. Gauthier D and Wiken EB (2003) Monitoring the conservation of grassland habitats, Prairie ecozone, Canada. Environmental Monitoring and Assessment 88:343-364.

8. Forrest SC, Strand $\mathrm{H}$, Haskins $\mathrm{WH}$, Freese $\mathrm{C}$, Proctor $\mathrm{J}$, and Dinerstein $\mathrm{E}$ (2004) Ocean of grass: a conservation assessment for the Northern Great Plains. Northern Plains Conservation Network and Northern Great Plains Ecoregion. WWF-US, Bozeman, MT.

9. Hammermeister AM, Gauthier D, and McGovern K (2001) Saskatchewan native prairie: statistic of vanishing ecosystem and dwindling resource. Native Plant Society of Saskatchewan, Saskatoon, SK.

10. Silva JP, Toland J, Jones W, Eldridge J, Thorpe ED, and O'Hara E (2008) LIFE and europe's grasslands: restoring a forgotten habitat. European Commission, Luxembourg.

11. Veen $P$, Jefferson $R$, Smidt $J$, and Styraaten J, eds. (2010) Grasslands in Europe of high nature value. KNNV Publishing, Zeist, NL.

12. Wiken EB, Gauthier DA, Schrag AM, Hoth J, Aguirre C, and Lafón A (2008) Temperate Grassland Region: North America. Compendium of regional templates on the status of temperate grasslands conservation and protection. Temperate Grasslands Conservation Initiative, Vancouver, BC.

13. Atkinson K (2009) Shared visions, shared wildernesses: wilderness conservation in the grasslands of Southern Saskatchewan. British Journal of Canadian Studies, 22.1, p. 87-114.

14. Lavrenko EM and Karamysheva ZV (1993) Steppes of the former Soviet Union and Mongolia. In Natural Grasslands. Eastern Hemisphere and Résumé, ed. R.T. Coupland, 3-59. Elsevier, Amsterdam.

15. Didukh YP, Tkachenko VS, Plyuta PH, Korotchenko IA, and Fitsailo TV (1998) Phytodiversity comparative estimate of preserved steppe ecosystems in Ukraine for optimization of conservation regimes. M.G. Kholodny Institute of Botany, National Academy of Sciences of Ukraine, Kyiv, UA.

16. Pachoski IK (1917) Description of the vegetation in the Kherson region. Vol. 2 Steppes. Estestvenno-istoricheskiy Musey Khersonskoho Gubernskogo Zemstva, Kherson, UA.

17. Kleopov YD (1933) The vegetation cover of the south-western part of Donetsk Kryazh. Visnyk Kyivskoho Botanichnoho Sadu 15:9-162.

18. Bilyk GI (1973) Meadow steppe. Typical (true) steppe. Herb-bunch-grass steppe. Desert steppe. Shrub steppe. Semi-savanna steppe. In Steppes, Screes, and Sands, ed. A.I. Barbarich, pp. 33-94, 94-170, 229-240, 245-249. Naukova Dumka, Kyiv, UA.

19. Moisienko I, Górski P, and Boiko $P$ (2002) Contributions to the flora of steppes. Roczniki Akademii Rolniczej w Poznaniu 347, Bot. 5:123-134.

20. Red Data Book of Ukraine. Vegetable Kingdom (2009) Globalconsulting, Kyiv, UA.

21. European Red List (2010) http:// ec.europa.eu/environment/nature/ conservation/species/redlist/index en.htm (accessed January 17, 2012). 
22. International Union for Conservation of Nature (IUCN) (2010) IUCN Red list of threatened species. Version 2010.4. http://www.iucnredlist.org (accessed January 17, 2011).

23. Green Data Book of Ukraine. Rare, threatened and typical plant communities that need protection (2009) Alterpress, Kyiv, UA.

24. Lillie M (2008) The Trypilian culture in context. In Mysteries of ancient Ukraine. The remarkable Trypilian culture 54002700 BC, ed. K. Ciuk, 11-16. Royal Ontario Museum, Toronto, ON.

25. Sudnik-Wójcikowska B, Moysiyenko II, Zachwatowicz M, and Jabłońska E (2011) The value and need for protection of kurgan flora in the anthropogenic landscape of steppe zone in Ukraine. Plant Biosystems, 145: 638-653.

26. Magocsi PR (2007) Ukraine: an illustrated history. University of Toronto Press, Toronto-London, ON.

27. Symko S (1999) From a single seed. tracing the Marquis wheat success story in Canada to its roots in Ukraine. Agriculture and Agri-Food Canada, Ottawa, ON.

28. Charles D (2010) Renewing the postSoviet steppe. Science 328:1225.

29. Curtin C, and Western D (2007) Grasslands, people, and conservation: over-the-horizon learning exchanges between African and American pastoralists. Conservation Biology 22:870-877.

30. Barry B (2001) Ukrainian people places. Centax Books, Regina, SK.

31. Kricsfalusy V, and Miller G. (2008) Invasion and distribution of Cynanchum rossicum (Asclepiadaceae) in the Toronto region, Canada, with remarks on its taxonomy. Thaiszia Journal of Botany 18:21-36.

32. Kricsfalusy VV, and Miller G (2010) Community ecology and invasion of natural vegetation by Cynanchum rossicum (Asclepiadaceae) in the Toronto region, Canada. Thaiszia Journal of Botany 20:53-70.

33. Hejda M, Pyšek P, Pergl J, Sádlo J, Chytrý M, and Jarošík V (2009) Invasion success of alien plants: do habitat affinities in the native distribution range matter? Global Ecology and Biogeography 18:372-382.

34. Osychnyuk VV (1973) Succession of the vegetation in steppe. In Steppes, Screes, and Sands, ed. A. I. Barbarich, 249-315, 373-398. Naukova Dumka, Kyiv, UA.

35. Tkachenko VS and Chupryna TT (1993) Changes in Striltsivskyi Steppe vegetation cover based on phytocoenological monitoring. Ukrayinsky Botanichny Zhurnal 52:252-259.

36. Tkachenko VS, Lysenko GM, and Vakal AP (1993) Changes in Mikhailivska Tzilina Reserve steppe vegetation based on 1991 large scale mapping. Ukrayinsky Botanichny Zhurnal 50:5-15.

37. Pan-European Biological and Landscape Diversity Strategy (1996) Council of Europes, Strasburg, France.

38. European Landscape Convention. (2000) Council of Europe. Florence, Italy.

39. Temperate grasslands. (accessed January 17, 2011). http://www.all-creatures.org/hope/gw/ biome_map temp_grasslands.jpg

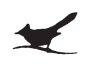

